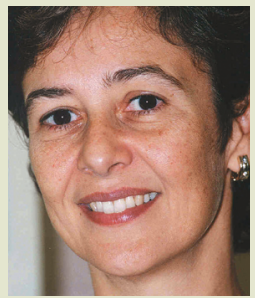

Tania Vidigal Limeira FGV-EAESP tania.limeira@fgv.br

\title{
marketing
}

\section{Comunicação e novas mídias}

APARELHOS COMO CELULARES, LAPTOPS, PALMTOPS E TOCADORES DE MP3 E MP4 TORNAM-SE CADA VEZ MAIS PLATAFORMAS DE COMUNICAÇÃO EM QUE OS USUÁRIOS TÊM MAIOR AUTONOMIA DE ESCOLHA E CAPACIDADE DE INTERAÇÃO, PARTICIPAÇÃO E CRIAÇÃO DE CONTEÚDO

Reconhecendo o poder de difusão dessas novas mídias, anunciantes, autoridades públicas, organizações sociais e celebridades delas se utilizam para transmitirem suas mensagens

Para anunciantes e publicitários, o desafio é integrar as novas mídias digitais e móveis com as mídias tradicionais, para aumentar a eficácia dos planos de comunicação de marketing, como explica McAndrews, da Microsoft: "Os consumidores passam cada vez mais tempo conectados, e esse movimento é irreversível. Essa mudança de comportamento requer outra forma de se fazer publicidade. Ninguém senta à frente de uma tela para assistir anúncios. Diante disso, a propaganda tem mesmo de ser relevante para reter a atenção".

Nos Estados Unidos, a participação da mídia digital está em torno de $8 \%$ do total de investimentos em publicidade no ano. No Brasil, embora ainda representem cerca de $4 \%$ da verba publicitária total, os investimentos em publicidade on-line aumentaram 47\% em 2007, em comparação com o ano anterior. Quanto à disseminação da web, um levantamento recente do Comitê Gestor da Internet mostrou que há 45 milhões de usuários da rede no país. Entre as tendências identifica- das, estão o aumento na posse de computadores em domicílios de renda familiar entre dois e cinco salários mínimos; o crescimento no uso da banda larga; e a expansão do uso das lan-houses como principais locais de acesso. Em relação às preferências dos usuários, 89\% a utilizam para comunicação, $88 \%$ para o lazer e $87 \%$ para a busca de informações e serviços. As atividades de comunicação mais utilizadas são: e-mails (78\%), sites de relacionamento (64\%), mensagens instantâneas (55\%) e blogs (13\%).

A propaganda on-line utiliza diversos formatos, como e-mails, banners, links patrocinados, vídeos, podcasts e blogs. Recentemente, surgiram os advergames, que é a publicidade dentro dos jogos virtuais. Porém, é nos sites de mídia social, como o MySpace, FaceBook, Wikipedia e YouTube, que se encontram as maiores oportunidades de interação com o público e construção de imagem para as marcas. O desafio é alcançar a melhor forma de comunicação de modo confiável e não invasivo. Para tanto, a premissa de base é sempre a mesma: o público não quer ser mero expectador, mas participar da criação de conteúdo, dar seu "toque pessoal" a todo relacionamento que se estabeleça pela web. $\boldsymbol{x}$ 